\title{
Unpacking the Black Utility Heuristic: Explaining Black Identification with the Democratic Party
}

\section{Maruice Mangum}

The aim of this research is to uncover the nature of the relationship between a black person's individual circumstances and their perceptions of group interests and party identification, concentrating on explaining blacks' identification with the Democratic Party. Data taken from the 1996 National Black Election Study is used to estimate blacks' party identification, testing individual interest and group-interest models. The results of the logistic regressions suggest that individual interests matter when predicting blacks' party identification. Unlike previous studies, I find that socioeconomic and demographic characteristics vary with blacks' party identification. Black Americans also rely on group-based political power and economic factors. Blacks' party identification is driven by evaluations of which political party is most useful to the black community.

Party identification is the psychological attachment one has toward a political party. It is psychological, for one does not have to join a party formally; all that is necessary is to declare your loyalty to one group or party over another internally. It is a key concept in American electoral politics research. A number of scholars have estimated the determinants of party identification as well as assessing its effects on issue positions, voting behavior, turnout, and presidential approval (Abramson and Ostrom, Jr. 1991; Miller and Shanks 1996). Some analyses have even examined the stability of party identification in the aggregate and the best ways to measure it (Abramson and Ostrom, Jr. 1991; Miller and Shanks 1996). All these studies have been concerned with the party identification of whites; the party identification of blacks was an afterthought. Much care has been given to understanding the party identification and strength of partisan loyalties among whites, but in comparison, not much attention has been given to the study of blacks' party identification and partisanship. That is, very few empirical efforts have been given toward this area of research. Largely, the only consistent, definite piece of knowledge we possess in this field is the actual party identification of most blacks.

Blacks overwhelmingly identify themselves with and support the Democratic Party. Electorally, blacks have been an important partner of the Democratic Party coalition since 1936, but especially since 1960 (Pinderhughes 1986; Walters 1988; Dawson 1994). The Democratic Party was the

MARUICE MANGUM is an assistant professor in the Department of Political Science at Southern Illinois University Edwardsville.

The American Review of Politics, Vol. 28, Spring, 2007: 37-56

(C)2007 The American Review of Politics 
first major party to provide blacks economic incentives in the 1930s, resulting in a realignment from the Republican Party to the Democratic Party (Walton 1985). Beginning in 1964, Black Americans have become one of the largest and the most loyal bases of support voting for the Democratic Party (Tate 1993). Identity soon followed as blacks moved in a near unanimous fashion to the Democratic Party beginning in 1964 (Carmines and Stimson 1989). This is not surprising, for the Democratic Party has become known as the party of racial liberalism, equality, and defender of the "have nots" since the 1960s (Carmines and Stimson 1989). Overall, the Democratic Party has been more active than the Republican Party in promoting the general welfare of blacks.

The transformation of the racial policy positions of the parties may be the reason for blacks' attachment to the Democratic Party. Enfranchised blacks voted for the Republican Party for three generations until the 1930s, when their loyalties benefited Franklin D. Roosevelt and the Democratic Party, and crystallized in continual support for the Democratic Party by the 1960s (Walton 1985; Pinderhughes 1986; Walters 1988; Tate 1993; Dawson 1994). Around 1964, the Democratic Party became more committed to establishing and maintaining the rights of blacks than the Republican Party. The Democratic Party has also been more supportive of governmental intervention in promoting social programs and protecting civil rights. Simultaneously, the Republican Party became conservative racially, and therefore, a less attractive alternative to blacks (Walton 1985). The transformation in which the Democratic Party became the party of racial liberalism and the Republican Party became the party of racial conservatism is reflected in mass perceptions of the parties, especially blacks (Carmines and Stimson 1982).

Black Americans are still identified predominantly as Democrats. According to a 2002 National Opinion Poll conducted by the Joint Center for Political and Economic Studies (Bositis 2002), 63 percent of the black respondents identified themselves as Democrats, $24 \%$ are self-identified Independents, and $10 \%$ stated the Republican Party is their party of choice. According to the 1996 National Black Election Study, 583 (48\%) of the 1,216 respondents are classified as strong Democrats, 236 (19\%) are classified as weak Democrats, and $183(15 \%)$ of the black respondents who first identified themselves as independents actually lean toward the Democratic Party. These numbers dwarf the numbers who identify themselves as Independents $(\mathrm{N}=83,7 \%)$, strong Republicans $(\mathrm{N}=23,2 \%)$, weak Republicans $(\mathrm{N}=24,2 \%)$, and Independents who lean toward the Republican Party $(\mathrm{N}=44,4 \%)$. The remaining $40(3 \%)$ black respondents in this data set did not know their party identification or refused to answer. 
Several scholars (Pinderhughes 1986; Walters; 1988; Walton 1990) have theorized about black support for the Democratic Party. They suggest that the affinity blacks have for the Democratic Party is due in part to a limited number of viable choices, or "structural dependence." They assert that because blacks are overwhelmingly liberal, the Democratic Party is their only real option. Supporting the Republican Party would not reap much benefit, if any at all. Blacks are too liberal to gain from becoming political independents or to believe moving to the center between the Democratic and Republican parties would be a wise move. Forming a third party or forging an alliance with one would be of very limited utility. The American party system works to the detriment of third parties and their candidates do not possess the resources to wage effective campaigns. Therefore, these scholars (Pinderhughes 1986; Walters; 1988; Walton 1990) conclude that blacks are "structurally dependent" on the Democratic Party.

Implicit in this argument is that blacks perceive enough policy differences between the major parties to continue supporting the Democratic Party over the Republican Party. Tate (1993) offers evidence to support this view. She finds that 73 percent of the blacks surveyed in a 1984 national survey of Black Americans believe the Democratic Party works hard on the issues important to blacks while only 25 percent believe the Republican Party works hard on those issues. Updating these data to include the findings from the 1996 National Black Election Study, reported in Table 1, 50 percent of the black respondents say the Democratic Party, and only 12 percent say the Republican Party, works hard on issues important to blacks.

According to Tate (1993), analyses addressing blacks' party identification have not explained why the majority of blacks are identified with the Democratic Party though there is plenty discussion of the factors that may be associated with this phenomenon. Tate (1993) and Dawson (1994) do not take into account the direct effects of the perceived racial responsiveness of the major political parties and group interests that will be done here. Relevant to this analysis, Tate (1993) accounts only for race identification and Dawson (1994) only the relative economic disadvantage of the black community. An alternative theory to the one posed by "structural dependency" theorists is tested here, one that is arguably applicable to more blacks as it does not assume the level of political knowledge or sophistication assumed by the spatial model of structural dependence. I test the black utility heuristic (Dawson 1994). It is a theory that claims to be an easier and more efficient method for blacks to decide which party is most beneficial to the race because individual blacks think or behave according to what is best for the race, not necessarily themselves.

The goal of this investigation is to increase our knowledge of the dynamics behind blacks' party identification, but more specifically, gain a 


\section{Table 1. Descriptive Statistics of Key Variables, N (\%)}

"Generally speaking, do you usually think of yourself as a Republican, a Democrat, an Independent, or what? Would you call yourself a strong Republican or a not very strong Republican? Would you call yourself a strong Democrat or a not very strong Democrat? Do you think of yourself as a closer to the Republican Party or the Democratic Party?"

$\begin{array}{ll}\text { Strong Republican } & 23(2 \%) \\ \text { Weak Republican } & 24(2 \%) \\ \text { Independent-Republican } & 44(4 \%) \\ \text { Independent } & 83(7 \%) \\ \text { Independent-Democrat } & 183(15 \%) \\ \text { Weak Democrat } & 236(19 \%) \\ \text { Strong Democrat } & 583(48 \%)\end{array}$

"How hard do you think the Democratic Party really works on issues Black people care about?"
Not hard at all
$46(4 \%)$
Not too hard
$171(14 \%)$
Fairly hard
$426(35 \%)$
Very hard
$182(15 \%)$

"How hard do you think the Republican Party really works on issues Black people care about?"

$\begin{array}{ll}\text { Not hard at all } & 376(31 \%) \\ \text { Not too hard } & 302(25 \%) \\ \text { Fairly hard } & 98(8 \%) \\ \text { Very hard } & 49(4 \%)\end{array}$

"Among the three, which strategy is best for increasing the political power of Blacks in the United States?"

$\begin{array}{ll}\text { Support for the Republican Party } & 76(6 \%) \\ \text { Independent Black Political Party } & 457(38 \%) \\ \text { Support for the Democratic Party } & 626(52 \%)\end{array}$

"On the whole, would you say that the economic position of Blacks is better, about the same, or worse than whites?"
Worse
$652(54 \%)$
Same
$375(31 \%)$
Better
$111(9 \%)$ 
better understanding of why blacks are so attached to the Democratic Party by examining (1) the effects of social, economic, and demographic characteristics and (2) perceptions of, and robustness of, group interests. In addition to contributing to our knowledge of blacks' party identification, this study is also important because of Dawson's (1997) finding. He states that while blacks are identified with the Democratic Party, the strength of this allegiance has become increasingly volatile. Therefore, a focus on the factors likely to influence party attachment and the strength of party attachment is in order. Also, given the strong relationship between party identification and voter behavior, this study may also provide some insight about why blacks vote routinely for Democrats. A plausible argument can be made that what drives party identification also informs voting behavior.

\section{Modeling Black Party Identification}

That blacks identify themselves with the Democratic Party in large numbers is very well known, but there is a major omission in the literature explaining this phenomenon. In particular, lacking in the literature is a fullyspecified model that explains and tests more adequately the relationships between the individual black person's position in society and their group's (or race's) position in society and party identification. This investigation seeks to fill that void by testing the black utility heuristic and examining the relationship between (1) the individual black person's socioeconomic and demographic background and (2) general black group interests, and how these are associated with blacks' party identification overall and particularly identification with the Democratic Party.

Using the 1996 Black National Election Study, I test whether blacks select the Democratic Party because it reflects their individual life circumtances or because it is in the interest of the group, or race as it were, or both. Specifically, this research will examine whether black Democrats and Republicans differ on (1) socioeconomic and demographic characteristics, especially with regard to education, income, labor union membership, public assistance status, and (2) their perceptions of black group interests. A comlete description of all the variables used in this analysis, their coding schemes, and predicted directions are found in the Appendix.

Studies have used data measuring socioeconomic and demographic characteristics to explain black affinity for the Democratic Party, arguing that this affiliation varied with class factors (Walton 1985; Tate 1993; Dawson 1994). Among other factors, those who enjoyed higher education and income were more likely to vote Republican than those who had less education and lower income. Many blacks find themselves on the low end of the education and income scales, and many of them are in the working class 
or the lower-middle class or they are related to someone who is in either of these classes. For them, identifying with the Democratic Party is rational because the Democratic Party is the party of the "have nots." Therefore, identifying with the Democratic Party would be logical for these blacks because this party is consistent with their economic, social, and political standing. Cumulatively, making the same utility calculus, blacks choose the same party. On the other hand, blacks may prefer the Democratic Party not because it aids them as individuals, but because they as a race of people usually gain when Democrats are in power. As a group, or a race, blacks perceive themselves as the beneficiaries of policy outputs by the Democratic Party more than they do from the policies of the Republican Party, and seeing the same reality, they label themselves Democrats.

\section{Individual Interest}

In this analysis I posit that blacks identify themselves with the Demoratic Party as a result of their social and economic positions (individual interest and socioeconomic and demographics are used interchangeably). That is, blacks may be Democrats because it reflects the current status of their resources or their resource-increasing ability. On the other hand, a lack of identification with the Democratic Party can also reflect the resources certain blacks possess or their resource-enhancing ability. It depends on their individual circumstances. Certain blacks may be predisposed to identify themselves with the Democratic Party, others may not, or it could be the case that individual (even family or household) considerations do not matter when predicting blacks' party identification and, more specifically, identification with the Democratic Party.

Like studies before, a number of socioeconomic and demographic characteristics and attitudes are used to account for the effects of blacks' party identification. The basic assumption guiding this portion of the analysis is the maxim: "Where you stand depends on where you sit." Certain blacks, due to their personal (family or household) circumstances, prefer the Democratic Party over the Republican Party because of the correspondence between their place in society and the party's theme, while others will not identify themselves with the Democratic Party, perhaps siding with the Republican and Independent parties, because of the connection between their life chances and for what these parties stand.

Education and income are related directly to identification with the Republican Party. Typically, we find that the well off and the "connected" associate themselves with the more conservative political party. Although Tate (1993) does not find that education and family income affect the party identification of blacks, the expectation is that these two indicators will be inversely related to identification with the Democratic Party and directly 
related to identification with the Republican Party. Blacks who are not high on the social ladder, especially those who receive or live with someone who receives some form of public assistance (ADC/AFDC, food stamps, Social Security, Supplemental Security Income, unemployment compensation, and worker's compensation), are expected to identify themselves more with the Democratic Party than blacks who find themselves in better economic conditions who are hypothesized to identify themselves more with the Republican Party.

Labor unions and the Democratic Party have been political partners for decades (Walters 1988). Until recently, the Democratic Party was virtually the sole beneficiary of the political participation of labor union members. While not as strong today, the tie between labor unions and the Democratic Party is still formidable. Therefore, I hypothesize that being a member of a labor union or living with someone who is in a labor union is related to Democratic party identification.

According to this socioeconomic and demographic model, blacks who are likely to benefit most from liberal and social welfare policies are hypothesized to extend their support to the Democratic Party more than blacks who are least likely to benefit from such policies. Blacks who perceive they are less likely to benefit from these policies are anticipated to be Republicans. If individual life circumstances matter when predicting the party identification of blacks, then (1) lesser educated blacks, (2) low income-earning blacks, (3) blacks receiving some public assistance or living with someone who does, and (4) blacks who belong to a labor union or live with someone who does will identify themselves more with the Democratic Party than the Republican Party, and the strength of party attachment is expected to intensify.

\section{Group Interest}

Based on the findings of previous research, group-centric indicators must be taken into account. Several scholars found powerful effects of group and race consciousness in shaping attitudes and behavior (Miller, Gurin, Gurin, and Malanchuk 1981; Shingles 1981; Gurin, Hatchett, and Jackson 1989; Tate 1993; Dawson 1994; Kinder and Sanders 1996). Additionally, Tate (1993) finds that race identification is a major component of blacks' party identification. She discovers that blacks who have high race consciousness are more likely to be Democrats than those who are not. Therefore, I examine the robustness of group interests for explaining blacks' party identification.

I hypothesize a positive relationship between the salience of black group interests (group or race consciousness) and identification with the Democratic Party. My argument is that black allegiance to a political party 
depends on the perceptions of the parties' responsiveness to the interests of the black community. I contend that blacks' party identification is explained in part by impressions of which party will best help blacks and advance their goals. Historically, blacks have identified with the party that best represented their interests (Dawson 1994). Gurin et al. (1989) state that blacks incorporate beliefs and attitudes about group membership and the status of the group in society into their political ideologies. They imply that it is this group consciousness that blacks use to create their party identification.

Underlying the discussion of group interests is the black utility heuristic. According to Dawson (1994), the black utility heuristic is used by many blacks because it is more efficient for them to determine what is good for the race than what is good for them personally, and more efficient to use the group (or race) status as a surrogate for individual utility. That is, it is easier for individual blacks to judge whether a policy, candidate, or party is beneficial to the group or race than to the individual. Dawson argues that the general consensus on many issues and policies among blacks stems from the strong relationship between the black individual's sense of their own interests and that of the race.

The guiding hypothesis is that evaluations of the major political parties by blacks are a function of group interests. If group or race interests matter, then blacks will identify themselves with: (1) the party that works harder on issues germane to the black community, (2) the party that will better increase the political power of blacks, and (3) the Democratic Party if they are concerned about the economic disparity between blacks and whites because the Democratic Party is believed to be the party of the "have nots." Again, the variables' wording, coding schemes, and predicted directions are in the Appendix.

Essentially, this model of group interests unpacks the black utility heuristic. The last of the above variables is included partly because, as Dawson (1994) contends, the association between the fate of the individual and blacks is emboldened when the individual believes his or her group is in a relative subordinate position economically. The relative economic status of blacks is a critical component in politicizing group interests and decision making by blacks.

The frequencies for the above responses give hope that these hypotheses will bear fruit. Found in Table 1 are the results of key survey questions (independent variables). Blacks surveyed in the 1996 National Black Election Study claim that when it comes to working on issues that black people care about, the Democratic Party is perceived as working "very hard" in the opinion of $182(15 \%)$ respondents compared with forty-nine $(4 \%)$ who say the Republican Party works "very hard." The number of respondents who say the Democratic Party works "fairly hard" is 426 (35\%), where only 
ninety-eight ( $8 \%$ ) believe the same of the Republican Party. The Republican Party is seen as working "not too hard" by $302(25 \%)$ black respondents and "not very hard" by 376 (31\%). A strong majority of blacks do not believe the Republican Party works hard on issues they care about, but only $171(14 \%)$ say the Democratic Party does not "work hard" and only forty-six (4\%) think the Democratic Party does not "work very hard" on these issues. Additionally, when it comes to the best strategy for increasing the political power of blacks, only seventy-six (6\%) believe the best route is to support the Republican Party, but $626(52 \%)$ believe that political power is best achieved by supporting the Democratic Party. Comparing their race's economic position with that of whites, $652(54 \%)$ of these black respondents say it is "worse," $375(31 \%)$ say it is the "same," and $111(9 \%)$ say it is "better."

\section{Control Variables}

Undoubtedly, the party identification of Black Americans is shaped by much more than individual factors and group interest. Therefore, beyond an accounting for them, I include controls for other demographic effects (indicators of age, gender, and southern residence) and political ideology to prevent spurious relationships. Due to a dearth of empirical studies that examine blacks' party identification, there is little by way of expectations to guide discussion here. However, two studies that sought to explain blacks' party identification have particular import for this analysis. Based on the findings of Tate (1993) and Dawson (1994), age is expected to have a positive relationship with Democratic identification and an inverse relationship with Republican identification and with other parties. Gender is a complicated variable. Dawson reports that being female is positively related to Democratic party identification among blacks, but Tate offers evidence to the contrary. Still, given the general likelihood that women are more likely than men to identify themselves with the Democratic Party, I hypothesize that black women, more so than black men, will identify themselves with the Democratic Party. I also expect southern blacks to be more Democratic than non-southern blacks, for that is what Dawson discovered.

Political ideology summarizes a lot of information concerning positions on politics and policies. More notably, political ideology encompasses attitudes about government action to ameliorate social inequalities, protect civil rights, and promote the economic welfare of its citizens. Liberalism is typically associated with supporting government intervention in the social, economic, and political realms of its citizens. Conservatism advances a limited role for government in these arenas. Not surprisingly, blacks support the liberal agenda (Dawson 1994). More important, Dawson discovers that liberalism is positively related to black identification with the Democratic 
Party. Therefore, the expectation is that black liberals are likely to state they are Democrats and black conservatives to report as Republicans, and with increasing strength. Political ideology is measured with an item that asks black respondents to classify themselves as either liberal, neither/refuses, or conservative.

\section{Dependent Variables}

The goal is to determine whether individual circumstances, group interests, or both affect blacks' party identification. Toward that end, I estimate a binary dependent variable that captures whether the black respondent is a Democratic Party identifier or not. Following Miller and Shanks (1996), a psychological indicator, not a behavioral one, is used to operationalize party identification. The standard survey item used to measure party identification is the typical party identification query ("Generally speaking, do you usually think of yourself as a Republican, a Democrat, and Independent, or what?").

Vigilant of the debate between traditionalists and revisionists, I still estimate party identification using a dummy variable. The debate involves the most appropriate way to measure party identification and not confusing it with partisanship. To be sure, partisanship encompasses more than simple party identification, for partisanship has many elements (Miller and Shanks 1996). Partisanship includes the strength of this attachment, electoral support, and policy agreement. Miller and Shanks (1996) assert that the first of the three questions constitute a true measure of party identification and the follow-up questions do not reflect party identification, but they do suggest partisanship. However, Franklin (1992) confirms the revisionist position, finding that the three survey questions produce a scale that is one "underlying, continuous dimension of party identification" (p. 299). Therefore, it does not matter whether I estimate blacks' party identification using a two, three, or a seven-point scale.

\section{Data and Methods}

This investigation analyzes data taken from the 1996 National Black Election Study. The sample size is 1,216 black voting-age respondents in the pre-election wave and 854 respondents in the post-election wave (an overall response rate of 65 percent in the pre-election phase and 70 percent response rate in the post-election phase). Random digit dialing was used to interview black households in the United States during the 1996 presidential election. Respondents were eligible for the survey if they were Black Americans and at least eighteen years old by election day. Interviewers simply phoned 
American households and questioned whoever answered if there was an adult that met these qualifications. If there was a black person who would be eighteen years of age by election day, the interview continued, otherwise, it was terminated.

The National Black Election Study is a telephone survey that focuses on black political attitudes and preferences. A wide range of topics is covered and a variety of questions are asked. This data set is also valuable, because it has a large number of cases to examine the party identification of blacks. However, the number of cases in the models ranges from 591 to 893 . The variation in sample sizes from one model to another is owed to the inability of the principal investigators to interview in the post-election those who participated in the pre-election wave and from missing cases due to incomplete surveys by respondents.

Previously, studies were impeded by a small sample size of blacks, rendering estimation and analysis unreliable if they were done empirically. The 1996 National Black Election Study is a significant substantive and methodological contribution to address the small-N problem of blacks included in the American National Election Study and General Social Survey. While the American National Election Study and General Social Survey are appropriate for analyzing typical predictors of party identification, they lack specific items that are used in this analysis. For instance, unlike the 1996 National Black Election Study, these data sets do not include questions that capture the effects of whether the political parties are working hard on issues of concern to blacks or how blacks should increase their political power. They do not implore respondents to give their comparative perceptions of the economic positions of blacks and whites. To use the American National Election Study and General Social Survey would not allow me to test the ideas I put forth. Again, using them would preclude reliable estimation of the party identification of blacks. Therefore, given the questions I seek to answer and the large sample of blacks, the 1996 National Black Election Study is the most appropriate and most recent study of Black Americans.

Yet, a more current data set would be preferable. A more recent national survey of Black Americans might be able to capture any effects of the Republican Party's growth in the South and focus on socially conservative issues. These two factors may have some import with blacks. They make up a sizeable portion of the southern population and are very religious and more conservative on religious issues than the general population. Recent moral and social issues might have attracted some blacks, though the attraction might be more applicable to vote choice rather than party identification. Whatever gains the Republican Party might have acquired in terms of attracting blacks may have been lost in the aftermath of Hurricane Katrina. 
Still, the 1996 National Black Election Study is useful, for blacks remain Democrats. Their pattern of identification has not changed, so the emphasis is on the factors that reinforce this attachment. To demonstrate the consistency of blacks' party identification further, the 2004 National Election Study shows that 61 percent of the blacks sampled identified themselves as Democrats and 80 percent either identified themselves with, or lean toward, the Democratic Party.

The method I use is to analyze the data is logistic regression. Logistic regression is used considering the skewed distribution of party identification among blacks. Variation is primarily within levels of Democratic partisan identification rather than between Democratic, Republican, and Independent. Therefore, I use logistic regression to estimate party identification as a binary variable and code the dependent variable whether blacks are Democrats or not.

\section{Empirical Analysis}

What are the determinants of blacks' party identification? What factors facilitate identification with the Democratic Party among blacks? To answer these questions, we now turn to the logistic regression results reported in Table 2 for the three models of blacks' party identification: Individual, Group Interest, and Combined. Displayed in this table are the unstandardized regression coefficients with the standard errors in parentheses. Because the purpose of this scholarship is to uncover the effects of individual and group interests on blacks' party identification, particularly, identification with the Democratic Party, discussion will emphasize the performance of the variables used to capture their effects.

\section{Individual Interest}

Can blacks' party identification and identification with the Democratic Party be explained by individual predictors? That is, do lesser educated, low wage-earning blacks, blacks receiving some form of public assistance, and blacks belonging to labor unions identify themselves more with the Democratic Party than their counterparts who are hypothesized to identify themselves with the Republican Party? Numerous studies have argued that those lower on the socioeconomic ladder are more likely to be Democrats than Republicans. Therefore, I hypothesized that blacks with less education, low family income, and receiving any of six types of public assistance or living with someone who does are inclined to identify themselves with the Democratic Party and the strength of this attachment is expected to be monotonic increasing. Also, in keeping with the standard socioeconomic status model, 
Table 2. Models of Black Party Identification

\begin{tabular}{|c|c|c|c|}
\hline Variables & $\begin{array}{c}\text { Individual Interest } \\
\mathrm{b} \\
(\mathrm{SE})\end{array}$ & $\begin{array}{c}\text { Group Interest } \\
\text { b } \\
(\mathrm{SE})\end{array}$ & $\begin{array}{c}\text { Combined } \\
\mathrm{b} \\
(\mathrm{SE})\end{array}$ \\
\hline Age & $\begin{array}{l}.030 * * * \\
(.006)\end{array}$ & $\begin{array}{l}.027 * * * \\
(.008)\end{array}$ & $\begin{array}{l}.025^{* * *} \\
(.008)\end{array}$ \\
\hline Gender & $\begin{array}{l}.549 * * * \\
(.158)\end{array}$ & $\begin{array}{l}.387^{* *} \\
(.205)\end{array}$ & $\begin{array}{l}.469^{* *} \\
(.219)\end{array}$ \\
\hline Southern Residence & $\begin{array}{l}.271^{* *} \\
(.154)\end{array}$ & $\begin{array}{l}.503 * * * \\
(.205)\end{array}$ & $\begin{array}{l}.652 * * * \\
(.221)\end{array}$ \\
\hline Political Ideology & $\begin{array}{l}.300 * * * \\
(.080)\end{array}$ & $\begin{array}{l}.234^{* *} \\
(.101)\end{array}$ & $\begin{array}{l}.257^{* *} \\
(.109)\end{array}$ \\
\hline Education & $\begin{array}{l}-.143 * * \\
(.075)\end{array}$ & & $\begin{array}{l}-.234 * * \\
(.110)\end{array}$ \\
\hline Family Income & $\begin{array}{l}-.013 \\
(.036)\end{array}$ & & $\begin{array}{l}-.047 \\
(.050)\end{array}$ \\
\hline Public Assistance & $\begin{array}{l}-.338^{* *} \\
(.173)\end{array}$ & & $\begin{array}{l}-.398^{*} \\
(.243)\end{array}$ \\
\hline Labor Union & $\begin{array}{l}.328^{*} \\
(.205)\end{array}$ & & $\begin{array}{l}.521^{* *} \\
(.275)\end{array}$ \\
\hline Black Issues Democrat & & $\begin{array}{l}.412 * * * \\
(.137)\end{array}$ & $\begin{array}{l}.369 * * * \\
(.146)\end{array}$ \\
\hline Black Issues Republican & & $\begin{array}{l}-.297 * * * \\
(.120)\end{array}$ & $\begin{array}{l}-.352 * * * \\
(.129)\end{array}$ \\
\hline Black Political Power & & $\begin{array}{l}1.167 * * * \\
(.166)\end{array}$ & $\begin{array}{l}1.220 * * * \\
(.173)\end{array}$ \\
\hline Black-White Economics & & $\begin{array}{l}-.423 * * * \\
(.158)\end{array}$ & $\begin{array}{l}-.551 * * * \\
(.170)\end{array}$ \\
\hline Constant & $\begin{array}{c}-0.679 * \\
(.414)\end{array}$ & $\begin{array}{c}-1.506^{* * * *} \\
(.538)\end{array}$ & $\begin{array}{c}-0.010 \\
(.738)\end{array}$ \\
\hline Total Cases & 893 & 627 & 591 \\
\hline Nagelkerke R Square & .093 & .258 & .280 \\
\hline Cases Predicted Correctly (\%) & 70.0 & 76.6 & 76.8 \\
\hline $\begin{array}{l}-2 \log \text { Likelihood } \\
\begin{aligned} * * & =\mathrm{p}<.01, \text { one-tailed test } \\
* * & =\mathrm{p}<.05, \text { one-tailed test } \\
* & =\mathrm{p}<.10, \text { one-tailed test }\end{aligned}\end{array}$ & 1035.626 & 620.584 & 568.804 \\
\hline
\end{tabular}


blacks belonging to a labor union or living with someone who does are expected to be Democrats instead of Republicans.

The data reported in column 1 of Table 2 suggest that individual circumstances do matter when explaining blacks' party identification. While the Individual-Interest Model explains very little total variance, three of the four key independent variables reach an acceptable level of statistical significance. However, one of these three key independent variables does not conform to expectations. The significant individual-interest variables that are in the anticipated direction include Education and Labor Union. As hypothesized, lesser-educated blacks are more likely to identify themselves as Democrats than well-educated blacks. Blacks who belong to a labor union or know someone who does are more likely to identify themselves as Democrats than blacks who do not. Public Assistance is surprisingly in the negative direction. According to the results of this variable, blacks who receive or live with someone who receives public assistance (one or more of the following: ADC/AFDC, food stamps, Social Security, Supplemental Security Income, unemployment compensation and worker's compensation) are more likely to identify themselves with the Republican Party and the strength of this attachment is positive. Even in preliminary analyses, not shown in Table 2, where each type of public assistance was allowed to have an independent effect on party identification, blacks receiving or living with someone receiving ADC/AFDC, unemployment compensation, and workers' compensation were more likely to be Republicans than Democrats. However, in the positive direction, but not significant statistically, were the relationships between blacks receiving or living with someone who receives food stamps, Social Security, and Supplemental Security Income. Nonetheless, unexpectedly, receiving public assistance predisposes blacks to be Republicans though conventional wisdom anticipates that they will be Democrats, for Democrats are more in favor of government assistance to the disadvantaged. While not significant, the Family Income variable is in the expected direction, indicating that low-income black earners are more likely to identify themselves as Democrats.

\section{Group Interest}

Are blacks' party identification in general and, more specifically, identification with the Democratic Party better explained by group interest? That is, do blacks identify themselves with the party they believe works harder on issues most salient to the black community and most able to foster black ascent to political power? Do blacks who believe their race is less fortunate than whites identify themselves more with the Democratic Party than the Republican Party? Several scholars have alluded to the tendency of 
blacks to view reality and make decisions based on the good of the group or race. Furthermore, race identification has been found to influence blacks' party identification. As a result, the hypothesis driving this portion of the analysis is that group interest, understood as the black utility heuristic, determines party identification. More specifically, given the championship of the general welfare of blacks by the Democratic Party, I expected group interest to be directly related to black identification with the Democratic Party.

The results of the Group-Interest Model are shown in column 2 of Table 2. This model explains a respectable amount of variance and it does a much better job of establishing relationships with blacks' party identification than the Individual-Interest Model. In fact, all four group-interest variables were significant and in the hypothesized direction in the model. Therefore, the conclusion of the Group-Interest model is that group interests (the black utility heuristic) shape blacks' party identification.

According to the Black Issues Democrat and Black Issues Republican variables, blacks who believe a certain party works harder on issues salient to blacks are more likely to identify themselves with that party. The Black Issues Democrat variable indicates that blacks who believe the Democratic Party works hard on issues black people care about are more likely to identify themselves as Democrats while the Black Issues Republican variable reveals that blacks who believe the Republican Party works hard on issues black people care about are less likely to identify themselves as Democrats. The Black Political Power variable also attests to the group-centric nature of blacks. It suggests that blacks choose the party that will best assist them in gaining political power. As expected, those who believe the best "strategy for increasing the political power of blacks" is by supporting the Democratic Party are likely to be Democrats and those who think that supporting the Republican Party to gain political power is most advantageous for blacks are apt to select the Republican Party. Lastly, the Black-White Economics variable is significant and in the hypothesized direction (because of its coding, it is expected to be inversely related to Democratic party identification). The results show that blacks who believe blacks are relatively deprived compared with whites, in that they perceive the economic condition of blacks is worse, are more likely to prefer the Democratic Party. Blacks who believe their race is better off than whites economically are likely to identify themselves with the Republican Party.

\section{Combined Analysis}

The third column in Table 2 displays the results of the Combined Model. In the Combined Model, all the variables in each of the Individual 
Interest and Group-Interest Models are used to estimate blacks' party identification. By placing all the variables in a single model, I am able to detect with greater confidence the factors associated with blacks' identification with the Democratic Party. The results of the Combined Model confirm what we learned from each of the Individual Interest and Group-Interest Models. When it comes to explaining blacks' party identification and locating the correlates of black Democratic party identification, both individual characteristics and group interests matter. Blacks use personal considerations and a group-based perspective to guide their party affiliation. Blacks' party identification is based on perceptions of which party will aid them most as a race than as an individual.

\section{Summary and Conclusions}

The purpose of this scholarship was to explain blacks' party identification, concentrating on explaining identification with the Democratic Party. Using the 1996 National Black Election Study, I estimated the effects of individual interest and group interest on blacks' party identification. An individual-interest model and a group-interest model were estimated separately, then in a combined model to solidify confidence in the findings in each model. In addition to these factors, each model included control variables. Even these controls conformed to expectations and were related to identification with the Democratic Party. The Age, Gender, Southern Residence, and Political Ideology variables were positive and significant in all three models. Older blacks, black women, blacks who live in the South, and black liberals are more likely to choose the Democratic Party than younger blacks, black men, blacks who live outside the South, and black conservatives, respectively.

This research produced two important findings. First, blacks do select a party based on their own socioeconomic and demographic situation. While previous studies were not able to find relationships among some social, economic, and demographic characteristics, this study does. Black Democrats are differentiated from other black party identifiers based on individual factors. The results support the longstanding notion that blacks are Democrats because of their socioeconomic status. While receiving public assistance does not encourage identification with the Democratic Party, blacks lower on the education scales and blacks belonging to a labor union or knowing someone who does are more likely to identify themselves as Democrats. As expected, based on the Family Income variable, blacks earning a lower income were more likely to be Democrats. However, the Family Income variable does not reach statistical significance in either model in which is included. The other individual-interest variable related to party 
identification, Public Assistance, was negatively related to identification with the Democratic Party. According to the socioeconomic and demographic model, blacks receiving or living with someone receiving public assistance from the government should be more likely to identify themselves with the party that will secure and protect these provisions. Yet, these respondents were not. So, one variable does as hypothesized, but the other does not, casting a shadow of doubt on the utility of individual factors for explaining the party identification of blacks.

The second major finding is that blacks use group interest (the black utility heuristic), or what is best for the race, to structure their party identification. In the Group Interest Model, all four variables measuring group interest were significant and in the anticipated direction. Furthermore, all four group-interest variables remained significant and in the hypothesized direction in the Combined Model. Blacks identified with the Democratic Party because they think it works harder on issues important to the black community and blacks who believed the Republican Party worked hard on such issues lent their support to that party. Additionally, blacks identified with the party they think would increase the political power of blacks. These findings suggest that the party identification of blacks depends on which party best represents the interests of the black community.

Blacks' party identification is very rational. Blacks identify themselves with the party that will help the race the most. The Republican Party abandoned blacks and the Democratic Party picked up the baton. The Democratic Party's positions on economic issues make individual-level considerations important when estimating the allegiance blacks have with a party. Black affiliation with a party is also structured by perceptions of the major parties' responsiveness to the interests of the black community. Specifically, blacks' party identification is explained by evaluations of which party will best help blacks achieve their goals. Inasmuch as the Democratic Party is perceived as the party that benefits blacks the most, it will reap electoral support from the black community. Therefore, the major implication of this article is that the likelihood that blacks will remain identifiers of the Democratic Party hinge on the willingness of the Democratic Party to remain the perceived champion of black interests.

Beyond the scope of this research, future research might examine how cognitive dissonance influences party identification. That is, some might identify themselves with a party not solely because it is viewed for being better for the group, but it may be that the belief a party will best serve the interests of blacks encourages identification with that party. 


\section{Dependent Variable}

Party Identification

Political Ideology (+)

Education (-)

Family Income (-)

Public Assistance (+)

Labor Union $(+)$

Black Issues Democrat $(+)$

Black Issues Republican (-)

Black Political Power (+)
"Generally speaking, do you usually think of yourself as a Republican, a Democrat, an Independent, or what? Would you call yourself a strong Republican or a not very strong Republican? Would you call yourself a strong Democrat or a not very strong Democrat? Do you think of yourself as a closer to the Republican Party or the Democratic Party?" $1=$ Democrat, $0=$ otherwise.

Age in years, ranging from 17-90.

$1=$ female, $0=$ male.

$1=$ South. $0=$ Non-South. South = Alabama, Arkansas, Florida, Georgia, Kentucky, Louisiana, Mississippi, North Carolina, South Carolina, Tennessee, Texas, Virginia, and West Virginia.

"Do you think of yourself as more like a liberal or more like a conservative?" $1=$ conservative, 2 = neither, refuses to choose, 3 = liberal.

$1=$ grade school (grades 1-8), 2 = some high school, no degree (grades 9-12), 3 = high school degree, $4=$ some college, no degree, 5 = Associate's/2-year degree, Bachelor's/4-year degree, $6=$ some graduate school, Master's degree, doctorate/law degree.

Combined income of all members of your family living with respondent, for 1995 before taxes.

"Did you or anyone in your household receive any other income in 1995 from:" ADC or AFDC, food stamps, Social Security, Supplemental Security Income, unemployment compensation, or worker's compensation? $1=$ yes, $0=$ no.

"Do you or anyone else in this household belong to a labor union?" $1=$ yes, $0=$ no.

"How hard do you think the Democratic Party really works on issues Black people care about?" 1 = not hard at all, $2=$ not too hard, 3 = fairly hard, $4=$ very hard.

"How hard do you think the Republican Party really works on issues Black people care about?" $1=$ not hard at all, $2=$ not too hard, 3 = fairly hard, $4=$ very hard.

"Among the three, which strategy is best for increasing the political power of Blacks in the United States?"

$-1=$ support for the Republican Party, $0=$ Independent Black Political Party, $1=$ support for the Democratic Party. 


\section{Appendix (continued)}
Black-White Economics (-) "On the whole, would you say that the economic position of Blacks is better, about the same, or worse than whites?" $1=$ worse, 2 = same, $3=$ better.

\section{REFERENCES}

Abramson, Paul R., and Charles W. Ostrom, Jr. 1991. "Macropartisanship: An Empirical Reassessment." American Political Science Review 85:181-192.

Bositis, David A. 2002. 2002 National Opinion Poll: Politics. Washington, DC: Joint Center for Political and Economic Studies.

Carmines, Edward, and James Stimson. 1982. "Racial Issues and the Structure of Mass Belief Systems." Journal of Politics 44:2-20.

Carmines, Edward, and James Stimson. 1989. Issue Evolution: Race and the Transformation of American Politics. Princeton, NJ: Princeton University Press.

Dawson, Michael. 1994. Behind the Mule: Race and Class in African-American Politics. Princeton, NJ: Princeton University Press.

Dawson, Michael. 1997. "African American Political Opinion: Volatility in the ReaganBush Era." Pp. 135-153 in African American Power and Politics: The Political Context Variable, ed. Hanes Walton. New York: Columbia University Press.

Franklin, Charles H. 1992. "Measurement and the Dynamics of Party Identification." Political Behavior 14:297-309.

Gurin, Patricia, Shirley Hatchett, and James Jackson. 1989. Hope and Independence: Black Response to Electoral and Party Politics. New York: Russell Sage.

Kinder, Donald R., and Lynn Sanders. 1996. Divided By Color. Chicago: University of Chicago Press.

Miller, Arthur H., Patricia Gurin, Gerald Gurin, and Oksana Malanchuk. 1981. "Group Consciousness and Political Participation." American Journal of Political Science 25:494-511.

Miller, Warren E., and J. Merrill Shanks. 1996. The New American Voter. Cambridge, MA: Harvard University Press.

Pinderhughes, Dianne. 1986. "Political Choices: A Realignment in Partisanship Among Black Voters?" Pp. 86-113 in State of Black America, ed. Janet Dewart. New York: National Urban League.

Shingles, Richard. 1981. "Black Consciousness and Political Participation: The Missing Link." American Political Science Review 75:76-91.

Tate, Katherine. 1993. From Protest to Politics: The New Black Voters in American Elections. Cambridge, MA: Harvard University Press.

Tate, Katherine. 1998. National Black Election Study, 1996 [Computer file]. ICPSR version. Columbus, OH: Ohio State University [producer], 1997. Ann Arbor, MI: Inter-university Consortium for Political and Social Research [distributor].

Walters, Ronald W. 1988. Black Presidential Politics in America: A Strategic Approach. Albany: State University of New York Press.

Walton, Hanes, Jr. 1985. Invisible Politics. Albany: State University of New York Press. 
56 | Maruice Mangum

Walton, Hanes, Jr. 1990. "Black Presidential Participation and the Critical Election Theory." In The Social and Political Implications of the 1984 Jesse Jackson Presidential Campaign, ed. Lorenzo Morris. New York: Praeger. 